\title{
In search of profit: housing association investment in private rental housing
}

\author{
Tony Crook ${ }^{1}$ and Peter A. Kemp ${ }^{2 *}$ \\ 1 Department of Urban Studies \& Planning, University of Sheffield, England, UK. \\ 2 Blavatnik School of Government, University of Oxford, England, UK.
}

\begin{abstract}
The traditional mission of housing associations in England is to provide non-profit housing let at sub-market rents to low-income and disadvantaged households. And yet in recent years, large 'property developer housing associations' have begun to invest in forprofit private rental homes let at market rents. Despite long waiting lists for their accommodation, these housing associations are mainly letting their for-profit rental homes to middle-income tenants rather than their traditional low-income clientele. Drawing on a 'historical institutional' conceptual framework, and combining structural and 'agency' explanations, this paper explores the reasons for this new trend. It argues that investment by large developer housing associations in for-profit and more upmarket rental homes will become increasingly important relative to their non-profit social housing. Over time, this 'partial recalibration' of their landlord role is likely to gradually transform the institutional rules, everyday practices and norms that shape their behaviour.
\end{abstract}

\section{KEY WORDS}

Housing associations; private rental housing; historical institutionalism; build to rent.

\section{Introduction}

This paper explores a puzzle: why are non-profit housing associations in England now building for-profit private rental homes to let at market rents? To put it another way, why are these social landlords adding private landlordism to their portfolio of activities in the housing market? This development is a 'puzzle' because it is a departure from their traditional mission as non-profit social landlords providing below-market rent homes to people in 'housing need'. (1) Indeed, one reason why governments in England began to fund housing associations (HAs) in the 1960s and 1970s was to provide an alternative to private landlords (Cullingworth, 1979). And yet, approximately a quarter of new purpose-built private rental homes are now being constructed by HAs. Not only are they being built for profit, HAs are letting them at market rents and very often to people who are better off than their 'traditional' social housing clientele.

This emerging trend is mainly confined to a small number of large HAs that have major development programmes and substantial reserves. Although it currently accounts for a small

*CONTACT Peter Kemp E: peter.kemp@bsg.ox.ac.uk 
part of their overall activity in the housing market, it is an increasingly important one. Moreover, some HAs have begun to acquire existing private rental housing portfolios - and one has even done so overseas. We argue that their private rental activities are likely to increase relative to their social housing. Combined with their other private development programmes the growth in their private rental housing could eventually raise the question of whether they are any longer primarily social housing landlords.

Back and Hamnett (1985) pointed out that HAs in England have historically had an 'ambiguous' character as partly private and partly public organisations: 'private' because they were not part of the public sector, but also 'public' because they received public funding and were regulated by government. This ambiguity has given HAs the ability to shift emphasis between public and private in response to government policy (Malpass, 2000). (2) More recently, scholars have classified HAs in England and elsewhere as 'hybrid organisations' because they are not wholly private, not wholly public and not wholly 'voluntary', but have attributes of more than one sector (Czischke et al, 2012; Mullins \& Pawson, 2010; Mullins et al, 2012). Billis (2010) showed that blurring of boundaries between private, public and voluntary sectors has increased since the global financial crisis. This reflects the organisational challenges that hybrids have faced due to privatisation and marketization (Mullins \& Walker, 2009; Rhodes \& Mullins, 2009). Social housing organisations across Europe have become more business-like and market-oriented in the wake of declining state funding (Czischke, 2009, 2014; Walker, 1998, 2000). Social housing landlords in both Australia and Europe have also entered the private market to generate funds (Gruis \& Nieboer, 2007). Meanwhile, Mullins et al (2012) showed that social housing organisations have varying private and public finance mixes; subsidiaries pursuing profit-making activities in order to cross-subsidise affordable homes; and a tenure mix combining social rented and market housing.

Classifying HAs as 'hybrid' organisations suggests they can choose between a range of institutional logics; and, if they pursue both market and social goals, have to resolve the tensions between them, especially as hybridity becomes more entrenched (Mullins, 2006; Mullins \& Pawson, 2010). However, HAs do not act in an unconstrained manner in choosing between these 'logics'. As Blessing (2012) has shown, whilst Dutch and Australian HAs combined private and public activities, their rules constrained them. They had legal and regulatory constraints on profit distribution and on commercial ventures that were unrelated to their missions. Moreover, change does not imply 'one-way journeys' from social to market housing: HAs may move in both directions, in response to changing circumstances. For example, Dutch HAs have recently retreated from a diversified strategy to re-focus on social housing (Nieboer \& Gruis, 2014, 2016). Furthermore, by itself hybridity does not explain shifts of emphasis between non-profit and forprofit logics; and nor why organisations evolve into or cease being hybrids. Thus, while classifying HAs as hybrids is helpful from a taxonomical perspective, it is less useful for analysing how and way they change over time, which is the subject of this paper.

Although there has been a growing literature about HAs embracing more private sector activity, the processes by which that change occurred have received less attention. Commentators have therefore argued that more research on the processes of change (Mullins et al 2012; Rhodes \& Donnelly-Cox, 2014), and more disciplinary perspectives, would provide a richer understanding 
of change (Rhodes \& Mullins, 2009). Morrison's (2016) study of two HAs in England showed how external pressures affected their organisational structures and practices when they diversified into private rental housing (cf. Sacranie, 2012). This paper takes a different approach and focuses on the macro level rather than the micro (organisational) level. It employs an historical institutional perspective to examine the puzzle of why non-profit HAs in England are investing in the private rental housing market. (3)

This article makes four main contributions to the literature. First, it provides empirical evidence about the scale of this recent growth in HA investment in for-profit rental housing. We show that most of this investment has been undertaken by a small number of large 'property developer' HAs. We also show that it has mainly been targeted on middle-income tenants, rather than their 'traditional' HA clientele of low-income and disadvantaged households; and to that extent, it involves a move upmarket. Second, the paper provides an in-depth analysis of why non-profit HAs in England are investing in for-profit residential property companies. In doing so, we show that the motives for that investment are much more complex than simply to crosssubsidize their social housing. Third, the paper illustrates the potential of an historical institutionalist perspective in housing studies. In particular, it shows the value of using that perspective to examine incremental changes to institutions that over time are transformative, rather than simply marginal adjustments along an existing institutional path. Our analysis suggests that the growing investment in for-profit rental housing has the potential over time to transform the nature and modus operandi of the 'parent' HAs. Fourth, the paper provides an important corrective to analyses of HAs that are overly focused on government policy and which pay insufficient attention to developments in the wider political economy. Although government policy changes are an important part of the story, other factors are also at work. In particular, the entry of HAs into the for-profit private rental market was facilitated by changes in the international political economy. Moreover, the future prospects of the for-profit property companies that HAs have established are likely to be affected more by developments in the wider political economy than by government housing policy.

The paper proceeds as follows. The second section outlines the conceptual framework historical institutionalism - that provides the analytical lens through which we examine the entry of HAs into private renting in England. The third section examines the scale of HA private rental investment. The fourth utilises the historical institutionalist framework to review the 'backstory' to HAs in England and in doing so describes a series of antecedent developments that led up to and made possible their entry into the private rental market. The fifth section looks at the changes in the institutional environment within which HAs operate that have prompted their investment in for-profit private rental housing. The final section pulls the empirical and conceptual evidence together, arguing that an historical institutional approach provides a helpful way of examining institutional change in housing provision.

\section{Analysing transformative change}

In this paper, we employ an historical institutional approach to examine the recent growth of investment in private rental housing by non-profit HAs in England. As Sanders (2006, p42) explains, historical institutionalist scholars are typically interested in "the construction, 
maintenance, and adaptation of institutions." This perspective seeks to examine the influence of temporal processes and events, and the timing and sequencing of changes, on the development of institutions over time (Fioretos et al, 2016). An historical institutionalist perspective enables us to better understand the dynamics of change over time, and the likely longer-term consequences, of this emerging trend.

Early historical institutionalist scholarship adopted the 'punctuated equilibrium' approach to institutional transformation (e.g. Steinmo et al, 1992) originally developed by economic historians working within a rational choice framework (e.g. North, 1990). In this model, exogenous shocks undermine an existing institutional equilibrium and thereby create the conditions for the emergence of a new one (Krasner, 1984). During these 'critical junctures' choices are made that set the newly created institution on a particular trajectory or path that becomes more entrenched over time due to positive feedback effects, making it very difficult to alter. Thus, critical junctures create 'path dependency' in which early developments shape later ones (Pierson, 2004). In essence, therefore, path dependency provides an explanation of institutional reproduction rather than change over time (Thelen, 2004).

In the punctuated equilibrium model, change is rare, discontinuous, and caused by shocks that are exogenous to the institution. In contrast, more recent historical institutionalist scholarship has focused on changes that result from endogenous processes that operate over time in ways that gradually transform institutions (Streeck \& Thelen, 2005). Gradual transformative change is by definition less dramatic than the discontinuous change captured by the punctuated equilibrium model, but it is far more common. The institutional changes that we examine in this paper are not the product of critical junctures, but rather the outcome of endogenous processes of gradual change that have the potential to transform housing associations as institutions.

In this paper, institutions are defined as a "relatively enduring collection of rules and organized practices embedded in structures of meaning and resources" (March \& Olsen, 2006, p.3). These formal rules, informal practices and shared meanings inform our understanding of how things operate and frame perceptions of how they should operate. They both produce, and help reproduce, everyday routines and taken-for-granted behaviour. Moreover, institutions create incentives and disincentives to act in certain ways and not in others; and in doing so help shape behaviour. Non-profit HAs are institutions (though not all institutions are organizations). The formal rules and informal practices, and the taken-for-granted assumptions, which structure the purposes and day-to-day modus operandi of non-profit HAs are generally different, for example, from those governing the behaviour of profit-focused private landlords. In March \& Olsen's (2008) terms, they have a different 'logic of appropriateness'. (4) Consequently, the ways in which they typically manage rental housing differ in relation to such tasks as tenancy allocation, rent setting and arrears recovery. While both types of landlord need to ensure that their income exceeds their outgoings, the excess is socially constructed in different ways - as a 'surplus' in the case of non-profit HAs and as 'profit' in the case of private landlords - each of which is imbued with different meanings and embodying, to some extent, different purposes.

Institutions have relatively 'settled' characteristics that endure over time; and, indeed, that is precisely what makes them institutions. Among the key characteristics of HAs in England since 
1974 are that they are non-profit landlords in receipt of public subsidy whose main (but not sole) purpose is to provide subsidized rental housing for low-income and disadvantaged households based on assessed 'need' rather than ability to pay. While the roles and institutional features of HAs have changed since 1974 the provision of below-market rent housing for people in 'need' on a non-profit basis remain their key defining features.

One precondition for institutional durability is that actors comply with the rules, practices and norms of behaviour that define the institution. Actors typically do so because these are takenfor-granted everyday practices. But they also comply because institutional rules and norms provide them with incentives to behave in ways that sustain the institution and not in ways that might undermine it. In addition, compliance with institutional rules may also be policed and sanctions applied to those who transgress them (Streeck \& Thelen, 2005). In the case of nonprofit HAs in England, for example, overseeing regulatory compliance is an explicit duty of the HA regulator, with which HAs must be registered in order to receive government subsidy, to whom they must submit financial statements of account, by whom they are subject to periodic inspections and whose governance standards and financial viability are formally rated (Morrison, 2016). (5) (6)

As well as 'official' policing, compliance may be monitored by other actors that form part of the institution. In the case of HAs that borrow from the international capital market, for example, 'unofficial' monitoring of compliance with institutional rules and accepted practices is undertaken by the credit-rating agencies, such as Fitch and Moody's. Failure to comply may result in an HA having a credit-rating downgrade, which would increase the rate of interest it pays on new loans and bonds or even prevent it from being able to borrow at all. For example, in 2016 two HAs had their credit rating downgraded because of their heightened exposure to market volatility and the growing scale of their for-profit activity relative to their core social housing role (Brown, 2016a; Stothard, 2016). This 'unofficial' policing is not a function of government policy and has instead developed to meet the need for investors to price risk in the international capital market. The credit rating agencies are key actors in the international political economy and have become part of the institutional architecture of HAs that borrow on the international capital market.

While institutions have relatively settled characteristics, they are not immutable. As Thelen (2004) has observed, the ability of institutions to evolve is an important reproduction mechanism that enables them to endure over time in response to changes in the environment within which they operate. Indeed, one reason why HAs have thrived is their ability to adapt to changes in the policy environment (Malpass, 2000). When the institutional environment changes in ways that threaten the relevance or existence of an institution, it needs to adapt its existing rules and practices, or develop new ones, in order to survive or thrive (Streeck \& Thelen, 2005). This adaptation does not happen automatically, but instead requires actors to exercise 'agency' to make it take place. Agency becomes especially important when the old rules and practices are called into question, but the way forward is uncertain or controversial. It is in these circumstances that 'change agents' (Mahoney \& Thelen, 2010) can make a difference. These actors seek to bend or subvert institutional rules in pursuit of their individual or organizational goals and ambitions. Success in doing so can prompt and encourage other actors ('follower 
agents' as we call them) to copy their example and bend or subvert the rules in similar ways. By themselves, change agents cannot transform institutional arrangements, but they can act at trailblazers, showing follower agents how they might respond to the new circumstances.

The type of gradual, but ultimately transformative, institutional change that is now taking place in relation to investment by HAs in private rental housing, is 'layering'. Thelen (2004) defines layering as the process whereby new institutional rules that have transformative potential are introduced alongside existing ones. Transformative potential exists insofar as the new rules embody a different modus operandi or alternative calculus from the old ('traditional') rules. Since these old rules remain in place, the new ones do not necessarily appear to threaten them. This is especially likely where the 'change agents' who advocate the new rules present them as a relatively minor adjustments, or as supplementary, to the old ones rather than as a replacement for them. Once in place and accepted, however, the new rules may eventually supplant the old ones (Mahoney \& Thelen, 2010). For non-profit HAs, investing in private rental housing represents a new set of institutional rules and practices that are operating alongside the existing ones governing their social housing.

'Layering' occurs where the new rules grow more quickly than the old rules and gradually overtake them in importance (Thelen, 2004). The new rules thereby become increasingly central to the survival or growth of the institution; and over time they gradually come to redefine its nature, purpose and modus operandi. Thus, institutional transformation via layering results from differential growth in the new rules relative to the old ones. Over time, this process of differential growth gradually alters the logic, everyday practices and taken-for-granted assumptions of the institution (Streeck \& Thelen, 2005; Mahony \& Thelen, 2010). Thus, as the process of layering picks up pace, it foreshadows the potential transformation of the institution. In this paper, we argue that the introduction by developer HAs of private rental investment alongside their traditional social housing, represents a form of layering. For reasons we discuss below, differential growth of the former relative to the latter seems likely to gradually transform the nature and modus operandi of these HAs as landlords.

\section{Investment in private rental housing}

In this section, we present new evidence on the growth in private rental investment by HAs in England. The data were extracted from the annual reports and financial statements of the 'top 50' developer HAs. Because HA accounts and financial statements are required to conform with UK financial reporting standards, they cover the same mandatory information. This includes dwellings owned and their tenure, the income and costs incurred in letting private and social rented dwellings, and information about the HA's strategies. They also include information on the fees paid to non-executive directors on their boards, which we report on later in the paper. We also extracted data from the Homes and Communities Agency's 'Global Financial Accounts' for HAs in the years from 2012 to 2016. These aggregate the financial statements of the largest HAs in England - those owning or managing at least 1,000 homes - which together account for 95 percent of all HA stock.

We also draw upon reports of new construction contracts published in two trade magazines 
(Inside Housing and the Estates Gazette) and a daily financial newspaper (the Financial Times). We also drew upon four other sources. The first was the British Property Federation's regularly updated Build to Rent Map (BPF, 2016). The second was the annual survey of HAs undertaken by Inside Housing, which collects information on the number of dwellings they had constructed during the year and their tenure. The third was a new survey of its members carried out by the National Housing Federation (the representative body for HAs in England) about the numbers of new homes completed in all tenures. The fourth was Government contracts signed under its Build to Rent Fund. These additional sources also provided information for the illustrative case studies referred to in the paper.

The data we collected show that recent investment in for-profit private rental housing is a growing part of HA activities in England. It is mainly confined to very large 'developer housing associations' that typically build their own stock, are active in the 'build-for-sale' housing market (see below), make substantial surpluses on their turnover, and have entrepreneurial CEOs and boards of directors. Thus, in financial year 2012/13, private rental accounted on average for $1.8 \%$ of the dwellings owned by the largest ('top 50 '), but for $6.2 \%$ owned by the seven HAs that had private rental portfolios of at least 500 dwellings (Table 1). By 2014/15, these figures had increased to $2.1 \%$ and $7.1 \%$ respectively. In other words, for those seven HAs, private renting accounted for one in 14 of their dwellings. Moreover, by the latter date, the number of HAs with $500+$ private rental dwellings had increased from seven to ten. Collectively, these ten were responsible for $87 \%$ of all private rental dwellings held by the 'top 50 ' HAs.

Thus, for these ten large HAs, investment in private rental housing is a substantial and rapidly growing activity - and a clear example of institutional layering. Moreover, developer HAs have become important actors in the nascent build-to-rent private market in England, that is, dwellings designed and built specifically for letting to private tenants. For example, in 2015/16, the 'top 50' HAs constructed 1,630 build-to-rent homes (Inside Housing, 2016) which accounted for $5 \%$ of their new construction. For the ten HAs with portfolios of $500+$ private rental dwellings, it accounted for $13 \%$ of their new construction.

We estimate that HAs account for a quarter of all new build-to-rent dwellings. Table 2 shows the number of private rental dwellings in contracts announced between January 2010 and April 2016 in the Financial Times, Estates Gazette and Inside Housing. Over that period, HAs contracted to build 7,238 build-to-rent dwellings (some in partnership with the private sector), which accounted for over a quarter of all new build-to-rent dwellings. This evidence is confirmed by British Property Federation (BPF) data, which indicates that 7,749 new private rented dwellings were contracted by HAs over the same period (BPF, 2016). As well as their own private rental construction, HAs bought new homes for private letting 'off-the-shelf from private developers and acquired existing private rental portfolios from other private landlords. In 2012, for example, they spent $f^{275 m}$ acquiring 2,015 new and existing dwellings for their private rental portfolios from other developers and private landlords (Savills UK Residential Research, 2013).

As well as private rental new build and existing portfolio acquisitions, developer HAs sold some 'poorly performing' private rental homes. 'Churning' portfolios in this way is standard practice amongst private property companies; and hence it is no surprise that HAs were also doing this. 
For examples, Places for People bought 654 private rented flats in England in 2013 from the developer Urban Splash, funded by $f_{777}$ of capital receipts from stock disposals (Inside Housing, 2013). Meanwhile, Circle HA purchased a Dutch private rental portfolio to add to its existing German private rental portfolio of 1,000 dwellings, which were acquired through its Guernsey subsidiary (Apps, 2014a). Circle later sold off the German portfolio, having benefited from capital growth (Brown, 2016b).

Some HAs have taken advantage of the government's Build to Rent Fund, which was established to encourage financial institutions to invest in new private rental housing. It provides $£ 1$ bn of short-term, repayable loans in order to 'de-risk' the development period. By May 2015, HAs accounted for a quarter of the 3,824 new dwellings contracted through the Build to Rent Fund. For example, A2 Dominion Group HA bought 102 homes from developer Crest Nicholson in the Southampton docks development, financed with $£ 3.5 \mathrm{~m}$ from the Fund. It also invested in a joint venture with Aviva Investors helped by an allocation from the Fund (Hammond, 2013). Notting Hill Housing Trust received $£, 17.7 \mathrm{~m}$ to build 181 private rental homes in London; and Derwentside Homes received $£ 4.8 \mathrm{~m}$ to build 114 private rental homes in Durham.

Developer HAs have made substantial and increasing financial surpluses from their private rental activity. The annual financial statements for the 'top 50' HAs show that, in 2015/16, their combined private rental turnover was $£ 150 \mathrm{~m}$, on which they made a surplus of $£ 82 \mathrm{~m}$. The median surplus for all HAs was $£$,, 705 per dwelling. The data in Table 3 show that income from private rentals constituted a growing share of the turnover of the 'non-social' housing activities undertaken by registered HAs (i.e. excluding income from unregistered subsidiaries), rising from $£, 92 \mathrm{~m}$ in 2012 to $£ 130 \mathrm{~m}$ in 2015 . By the latter date, private rental dwellings accounted for 15 per cent of all 'non-social' turnover. Private rental turnover was concentrated in a small number of HAs, with the top ten HAs (in stock size) accounting for 60\% of the total in 2015.

Registered HAs with only de minimis numbers of private rental homes are not in breach of registration rules or charity law and can therefore hold them within their existing organisation. But registered HAs with more than modest private rental portfolios are required to own them within non-charitable, unregistered subsidiary companies. Using subsidiaries enables registered HAs to adopt property management rules and practices that are geared to the exigencies of the private rental market, unconstrained by the existing rules that are in place for their social rented housing. However, unregistered HAs are not free of institutional rule-policing. As Morrison (2016) noted, registered 'parent' HAs are required by the HA regulator to ensure that their unregistered subsidiary companies properly manage the risks of owning private rented homes and do not place at risk the social housing assets held by the 'parent' HA. Profits made by unregistered subsidiaries are liable for Corporation Tax, but these are tax-exempt if they are 'donated' under the Gift Aid scheme to the parent HA. Gift Aid payments from their subsidiaries constitute a growing source of income for registered HAs.

\section{Institutional adaptation over time}

HAs in England first came to public attention in the nineteenth century when 'model dwellings' companies were established by wealthy philanthropists concerned about the poor quality and 
shortage of housing for working people. Their aim was to demonstrate that private enterprise could provide decent housing at affordable rents for the 'respectable' poor. The model dwellings companies were for-profit organizations but sought to achieve a below-market return of their investment. Some described this movement as ' $5 \%$ philanthropy' because their target rate of profit was below the $8 \%$ gross yield typically obtained from working class rental housing at the time (Tarn, 1974).

Despite the public attention that the model dwellings movement achieved at the time, they accounted for a negligible share of the housing market in England (Merrett, 1979). When public subsidies for rental housing were introduced after the First World War, they were largely aimed at local authorities. In contrast to some countries in mainland Europe, in the interwar years it was local authorities and not HAs that became the predominant type of social housing landlord in England (Harloe, 1995). After the Second World War, the HA movement witnessed modest growth and increasing diversity. Some HAs were set up by employers, but more often were established by community activists, faith groups and others to meet local housing needs. Meanwhile, some new HAs were established during the early 1960s in response to government initiatives as an alternative to the rapidly declining private rental sector (Cullingworth, 1979; Malpass, 2000).

Notwithstanding these post-war developments, HAs played a relatively minor role in housing provision in England until the 1970s. After the Housing Act 1974, new HAs were established and existing ones grew at an accelerated rate (Back \& Hamnett, 1985; Crook \& Moroney, 1995). The Act introduced a generous financial regime for HAs that enabled them to build new homes or acquire and rehabilitate sub-standard private sector ones. Under this financial regime, HAs benefited from 100\% public funding - capital grant plus public sector loan - and were fully insulated from development risk (Crook \& Moroney, 1995; Hills, 1987). In effect, HAs had become more like public organizations; and indeed many contemporary observers regarded them as public sector landlords. The idea of entering the for-profit private rental market would have seemed inconceivable, and even objectionable, to the non-executive management committees of HAs during this period.

The 1974 Act financial regime engineered a transformative institutional change in the nature of and role of HAs, setting them on a new 'developmental path' that lasted for a decade and a half. It was not the outcome of a 'critical juncture' caused by an exogenous shock that undermined the previous institution. HAs could have continued in the same way as before, but not surprisingly were quick to take advantage of funding from government that made new construction virtually risk-free and thereby enabled them to meet housing needs on a much bigger scale. Nevertheless, it was a transformative change and an example of institutional 'displacement', a process described by Streek and Thelen (2005) as the removal of old rules and introduction of new ones. The new rules included compliance with the Housing Corporation, which was the government agency responsible for their supervision. The reorientation of HAs away from the private and towards the public was reflected in a corresponding shift away from the middle-market that some had previously focused upon and more towards low-income and disadvantaged households (Crook, et al, 2016a). The 1974 financial regime significantly increased the role and importance of HAs, turned many of them into large-scale housing management 
organizations, and made it possible for some to become housing developers.

Although few would have imagined it at the time, the 1974 financial regime was an antecedent change that helped pave the way to HA involvement in the private rental market. The next turning point in the sequence of changes in that institutional transformation occurred in the 1980s with a shift to mixed public/private funding. By then, HAs were firmly established as a key provider of social housing and some of the larger ones had accumulated substantial property and financial assets (Lupton et al, 2011). In the mid-1980s, North HA (the largest HA in England at the time) experimented with private finance in combination with higher rents and lower capital grants. North HA was an example of an institutional 'change agent' (Mahony \& Thelen, 2010). Change agents adapt or bend existing institutional rules in innovative ways that are subsequently copied by 'follower agents' and which ultimately transform the institution. What caused the other HAs to follow in North HA's wake was the 'new financial regime' introduced in 1988/89 by the Thatcher Government, which borrowed from North HA's mixed funding experiment.

As part of a wider plan to 'de-municipalise' rental housing (Kemp, 1990), the Conservatives shifted HA development away from 100\% public funding to a mix of private-public funding. Henceforth, capital grant was fixed in advance and loan finance sourced from the private and not the public sector; per unit capital grant was reduced (such that loan finance accounted for a larger share of development costs than under the 1974 Act financial regime); and rents on new lettings were deregulated, thereby enabling them to rise to a level that could service the higher interest rates charged on private sector loans (Randolph, 1993). Under this new regime, therefore, new construction and refurbishment by HAs were no longer fully insulated from development risk. Instead, they were now to be subject to what the Conservative Government described as 'the disciplines of the market' (DoE, 1987).

The 1989/90 financial regime was not the product of an exogenous shock, but instead was another example of 'displacement'. It created a new set of institutional rules governing the development of new social housing by HAs, which replaced the old rules for the finance of new housing and required new working practices and norms. In order to better manage the risks and imperatives of the 'market disciplines' to which they were now exposed, many developmentoriented HAs made two significant and related changes to their management committees. First, from the early 1990s they increasingly recruited committee members with expertise in finance, law, commercial real estate and related professions. The days when, say, social workers or teachers were invited to join HA committees were more or less over, as they were not seen as having the financial, legal or real estate expertise that the new financial regime required.

Secondly, after 2003 HAs in England were allowed to pay their committee members (Mullins \& Pawson, 2010). This controversial reform followed lobbying by some of the larger HAs and represented a change in the institutional rules and practices that shaped their behaviour. Instead of giving their time for free, committee members were being financially compensated for doing so. The altruistic 'gift relationship' (Titmus, 1970) embodied in committee membership was thereby turned, at least in part, into a financial one. Moreover, the sums involved are substantial. Our analysis of the financial statements of the 'top 50' HAs in 2015/16 revealed that 45 of them 
paid fees to their non-executive board members. Furthermore, there was a statistically significant correlation between the size of their private rental portfolio and the amount of fees they paid to board members and chairs (Pearson's correlation coefficient of +0.6 in the case of chair's fees). Among the ten HAs with $500+$ private rental dwellings, the average annual fee paid to chairs was $£ 27,923$. For comparison, median pre-tax annual earnings for full-time employees in 2015/16 were $£ 28,200$. Most chairs would be expected to spend 3 to 4 days a month on HA business.

Both developments almost certainly helped to increase the commercial orientation of these HAs and was something the regulator actively encouraged as a means of ensuring that financial risk was well-managed to help protect publicly-funded social housing assets. The role of HA committee members had become more akin to that of the 'non-executive directors' sitting on private company boards. Indeed, HAs increasingly referred to their governing committees as 'management boards'. This in turn increased the potential to transform the institutional norms, expectations and hence practices of these HAs and their willingness to invest in private rental housing. In this way, changing discourse can help reinforce and legitimate new institutional practices.

The more private orientation for HAs under the 1989/90 financial regime was more in tune with the ideological sensibilities of the Thatcher Government. It was also a way of increasing the role of HAs while reducing that of local councils in rental housing provision. New construction by LAs had already been substantially reduced since the late 1970s and the Conservatives now introduced a range of measures that they hoped would result in LAs ceasing to be landlords altogether (Kemp, 1990). These measures created an environment of institutional constraints and incentives that prompted a growing number of local authorities to sell their housing stock to new HAs that they set up to acquire and manage them. About half of all local authorities have sold their housing stock to new HAs in this way, thereby shifting them from being fully public to quasi-private organizations (Pawson \& Mullins, 2010). Stock transfers are a form of 'displacement', that is, the removal of existing institutional rules and the introduction of new ones (Streeck \& Thelen, 2005). Stock transfer HAs are examples of what Billis (2010) refers to as 'enacted' hybrid organisations. Our analysis of HA financial accounts indicates that they had no private rental income in $2014 / 15$. Hence, it is only 'organic' hybrids that had invested in private rental housing at that date.

Meanwhile, in order to maximize their use of private finance and achieve economies of scale, many existing ('organic') HAs grew in size, not only via new construction, but also by mergers with others (Pawson \& Mullins, 2010; Pawson \& Sosenko, 2012). These processes helped create a group of large HAs that were highly entrepreneurial, more willing to take risks, had substantial reserves, generated significant surpluses each year, and were able to take advantage of the new opportunities that financial deregulation had created in the international capital market (cf. Mullins \& Pawson, 2010). Moreover, in the new financial regime, HA private loan debt was implicitly underwritten by the government because the HA regulator monitored their financial strength and risks; and intervened when necessary to ensure that their assets were protected. This implicit government guarantee provided 'comfort' to private lenders and reduced the rate of interest that HAs would otherwise have had to pay. Thus, government underwriting was a critical feature of the institutional architecture of developer HAs in the mixed public/private 
financial regime. Although they received less funding per dwelling constructed than under the 1974 Act regime, HAs remained dependent on government and subject to oversight by the HA regulator.

The new financial regime introduced in 1989/90 helped reshape the institutional architecture, logics of action and modus operandi of HAs in England. It set them on a new 'developmental path' of mixed public/private finance, which over the next decade enabled them to grow their development programmes, increase their asset base, enhance their risk management capacity, and acquire new finance market expertise. That in turn enabled them to diversify into new and more market-focused activities. From the turn of the century, large developer HAs began to diversify into the 'build-for-sale' market'. Making profits through building new homes for sale enabled them to take advantage of rapidly rising house prices and generate surpluses with which to crosssubsidize their social housing (Morrison, 2016). The new wave of HA investment in private rentals forms part of this diversification strategy employed by the larger developer HAs. Like the 1974 Act regime that preceded it, the 1989/90 financial regime was an antecedent change that helped to pave the way for the recent surge of investment by non-profit HAs in for-profit private rental housing. Each of these transformative changes in institutional architecture - and its associated rules, norms and practices - built upon, and would not have been possible without, the one that preceded it.

\section{Moving into the private rental market}

Since the global financial crisis, further changes in the environment within which HAs operate have accelerated the institutional transformation of large developer HAs. These changes to the institutional environment include developments in the international political economy as well as reforms to domestic housing policy. In this section, we examine the ways in which these changes have created incentives for them to invest in private rental housing. We then explore the ways in which HA 'change agents' have led the way to take advantage of this changing institutional environment.

\section{5a. Changing institutional environment}

The growth and diversification of HA activities under the 1989/90 financial regime was facilitated by developments in the international political economy. The 'secular decline' in global interest rates that occurred during the 1990s and into the new century meant that developer HAs could borrow more cheaply. Moreover, the global 'savings glut' meant that the supply of credit became more plentiful, and the terms on which it could be borrowed became more lax, developments that helped produce the housing boom in many advanced economies from the mid-1990s to the mid-2000s (Schwartz, 2009). One critical economic consequence of the subsequent global financial crisis was a shift towards an even lower interest rate regime. This was a market reaction to slow and faltering growth in the wake of the financial crisis. It was further entrenched by quantitative easing programmes undertaken by the central banks of the USA, UK and Eurozone, in order to encourage investment and a return to more robust growth. As a result, government bond yields fell to unprecedentedly low levels. Low bond yields in turn led to a world-wide 'search for yield' among corporate investors including pension funds, life assurance companies and sovereign wealth funds (Kemp, 2015). This search for safe, but higher-yielding, 
investments increased their willingness to provide loans and equity finance to HAs in England. The new cheap money regime also made it possible for developer HAs to issue bonds, at low rates. Some HAs began to issue private placements because, unlike bonds, they do not require a credit rating, and have less onerous conditions than bank loans. Pension funds and life assurance companies became more willing to provide equity finance for HA investment in private rental housing because the returns were higher than on lending to HAs for social housing (Pawson \& Milligan, 2013; Tang et al, 2017) and on government bonds purchased in the international capital market.

A key political response to the global financial crisis was for governments to embark on fiscal retrenchment in order to cut their deficits and debt levels (Crawford, et al, 2011), both of which increased sharply as a result of the crisis and subsequent recession. In England (and the UK as a whole) this new era of fiscal austerity had an ideological imperative under Prime Minister David Cameron and finance minister George Osborne, who saw it as an opportunity to 'shrink the state' back to 1948 levels (Taylor-Gooby, 2012). Fiscal austerity included substantial cutbacks in capital grants for HAs (Wilcox \& Pawson, 2013; Morrison, 2016). Not only was the total amount of capital grant greatly reduced, but the amount per dwelling constructed was also cut, thereby reducing the financial viability of some new developments. This caused substantial shrinkage in HA social rental building programmes.

Fiscal austerity gave large developer HAs an additional incentive to invest in for-profit rental house-building. Along with build-for-sale, this provided HAs with a way to maintain their development programmes in the face of cutbacks to social housing construction. It also enabled them to maintain their cash-flow and avoid staff redundancies. A further rationale was that the profits could be used to cross-subsidize their social house-building (Morrison, 2016; Manzi \& Morrison, 2017). The financial viability of social housing construction was further undermined by the government decision to enforce a $1 \%$ per annum reduction in real (after inflation) rent levels in social housing from 2015/16 to 2019/20. In historical institutionalist terms, this unexpected cut in real rents represented a post hoc change in the institutional rules governing social housing construction. It was also damaging for HAs that had borrowed from the capital markets based on assumptions about rental income growth, not decline. It therefore gave developer HAs an incentive to increase their investment in the private rental market (Morrison, 2016). Affinity Sutton HA, for example, announced that its development programme would involve fewer social and more private rental homes as a result of the $1 \%$ real cut in social housing rents.

Moving into the private rental market was not only about responding to institutional threats, but also about taking advantage of opportunities. It enabled large developer HAs to expand their development programmes and to increase their size as landlords. It also allowed ambitious HAs to move into new rental markets. As the Chief Executive of Notting Hill Housing Trust explained, their plan to invest $£, 500 \mathrm{~m}$ in private rental housing by 2018 "is not solely about creating crosssubsidy" for social housing. It was also about broadening their rental clientele (quoted in Brown, 2013b, p10) in response to the changes in market demand. In other words, it entailed a partial 'recalibration' of their institutional rules and practices as a landlord, from being exclusively focused on the poor and towards more upmarket tenants. 
This shift in emphasis highlights an important change in the role and nature of large developer HAs. On the one hand, the long-term decline in social housing is forcing increasing numbers of low-income tenants into private renting; paying market rents for what are typically short-term and hence insecure tenancies (Kemp, 2011). In theory, HAs could let their new private rental homes to tenants they normally accommodate in their social housing. Housing Benefit (an incomerelated housing allowance) would partly offset the higher rent that such tenants would face. And because HAs are long-term landlords, they could let their private rentals on indefinite ('assured') tenancies, or at least longer fixed-term ('assured shorthold') tenancies, than the one-year leases on which private landlords typically let their properties. In doing so, HAs would be able to provide the security of tenure that most private landlords are currently unwilling to offer lowincome households. Market rents combined with security of tenure is clearly a better deal for these tenants than is market rents combined with insecurity of tenure. On the other hand, the demand for private rental housing has also markedly increased from single people and couples who in the past would have bought their home - dubbed 'Generation Rent' by the mass media. As developer HAs have noted (cited by Brown, 2013b; Cowans, 2012), the rise of Generation Rent provided them with the opportunity to provide rental housing for middle-income households on a for-profit basis.

While some developer HAs have let their new private rental homes to their traditional lowincome clientele, others have not. Thus, Morrison's (2016) study of two English HAs found that Notting Hill Housing Trust saw this investment as being part of its social mission and house its 'traditional' tenants. Meanwhile, Thames Valley Housing saw its private rental activities as being wholly separate from its social mission and targeted on a different group of tenants. Drawing on the distinction made by Gruis (2008), Morrison (2016) argued that Notting Hill was a 'societal housing innovator' undertaking a range of activities but which was still focused on its core social housing business; and Thames Valley was a 'societal real estate investor' active in the commercial sale and rental markets. For the purposes of this paper, these two contrasting types of HAs might be better labelled as 'social housing developer' and 'property market developer' associations respectively.

Our analysis of the strategy statements in the annual reports and financial statements of the 26 HAs in the 'top 50' who had non-trivial private rental portfolios found that 15 were focused on their traditional clientele and 11 were targeting better-off tenants. But while 'social housing developer' HAs had an average private rental stock of 260 dwellings, 'property market developer' HAs had an average private rental portfolio that was eight times higher at 2,064 dwellings. This suggests that most of the growth in private rental investment is being made by property market developer HAs who are targeting tenants who are better-off than their traditional social housing tenants. In other words, their private rental investment represents an 'upmarket' shift in their role as landlords.

This move 'up market' by property developer HAs coincided with a decision by David Cameron's Conservative Government in 2015 to refocus HA construction subsidies onto 'starter homes' for owner-occupiers and shared ownership (part buy, part rent) instead of social housing. (7) Although Theresa May's Conservative Government subsequently modified this 
requirement, it is clear from the Housing White Paper (DCLG, 2017) that starter homes and shared ownership are likely to dominate new subsidized housing provision by HAs for the foreseeable future. This re-orientation of HA subsidies represents a government-engineered form of institutional 'conversion' of the primary role of developer HAs, shifting them towards being promoters of homeownership. Conversion represents another form of gradual but transformative change (Streeck \& Thelen, 2005). It will inevitably reduce the amount of new social housing that developer HAs can build and further increase their incentive to invest in forprofit private rental housing. And it will also reinforce and accelerate their shift upmarket, away from low-income households and towards middle-income households. Indeed, the 2017 Housing White Paper announced an increase in the income limit for new subsidized ('affordable') homeownership schemes to $£ 80,000$ per annum: approximately three times average incomes in England.

This recalibration of property developer HAs - reduced building for social renting, greater focus on shared ownership, the introduction of 'starter homes', and more upmarket tenants complemented their entry into the build-for-sale (and for-profit) housing market that began at the turn of the century. Build-for-sale is likewise not aimed at the traditional HA clientele of lowincome and disadvantaged households, but rather at homebuyers. However, the build-for-sale market is not only profitable, but also more cyclical, and hence entails more financial risk than building social housing. This volatility has given property developer HA a further motive to invest in private rental housing construction. As several HAs have noted (cited in Apps, 2014a), private rental investment can act as a 'counter-cyclical regulator' to the more volatile build-forsale market. For example, Places for People (2016, p26) noted that it had "the ability to deliver a business that is resilient and able to act both cyclically and counter-cyclically. If the market drops, the Group is well positioned to change the tenure of new housing to market rent for institutional funders in order to protect revenues standards". When the build-for-sale market enters a downturn, unsold homes can be 'mopped up' by their private renting subsidiary companies and more of their development pipeline can be devoted to private rental until the for-sale market picks up again. Thus, private rental housing can act as a 'counter-cyclical regulator' for HA development.

Another stimulus for entering the private rented market has been the government's coercion of HAs to implement a 'voluntary' right to buy for their social housing tenants (Morrison, 2016). This initiative mimics the statutory Right to Buy (and accompanying purchase discounts) introduced for council housing tenants in 1980. The voluntary Right to Buy represents another government-enforced post hoc change in the institutional rules and practices governing social housing. Because it only applies to their social housing tenants, the voluntary RTB increases the incentive for developer HAs to invest in private rental housing. Doing so enables them to maintain their landlord function in the face of possible loss of their existing social housing through voluntary Right to Buy sales.

\section{$5 b$. The role of 'change agents'}

When the institutional environment changes in ways that threaten the relevance or existence of an institution, it needs to adapt its existing rules and practices, or develop new ones, in order to survive or thrive (Streeck \& Thelen, 2005). It is in these circumstances that 'change agents' 
(Mahoney \& Thelen, 2010) can make a difference. By definition, these actors seek to bend or subvert institutional rules in pursuit of their individual or organizational goals and ambitions. Success in doing so can prompt and encourage other actors ('follower agents' as we call them) to copy their example and bend or subvert the rules in the same or similar ways. By themselves change agents cannot transform institutional arrangements, but they can act at trailblazers, showing follower agents how they might respond to the new circumstances.

The role of 'change agents' in bending or subverting institutional rules in ways that 'follower agents' later adopt, was nicely illustrated in a feature article on David Cowans, chief executive of Places for People in the trade magazine Inside Housing. The article noted that Places for People had "raised eyebrows" among other HAs by rapid expansion that involved the acquisition of a range of businesses including two private rental management companies and several rental portfolios from private landlords. The article explained that his critics regarded Mr Cowans as pursuing a relentlessly commercial outlook that was diversifying Places for People away from social housing and converting it into a private property company. Meanwhile, his advocates believed he was providing innovative leadership that was "testing new ways housing associations can adapt to political realities to secure an independent future" (Duxbury, 2014, p13). The article quoted the chief executive of London and Quadrant HA, one of the largest HAs in England:

Often David will say something at a round table [discussion] and I will think, What are you talking about?' Then, months later, I will find myself agreeing. I think the [HA] sector needs leaders like David. He pushes boundaries and... it creates space for others to do more.

Three years later Places for People launched a real estate fund management company called PfP Capital. The rules, practices and norms governing PfP Capital are inevitably very different from those of non-profit social housing landlords letting homes at below market rents to low-income tenants. It was launched with $£ 150 \mathrm{~m}$ worth of Places for People's existing property and planned to attract a further $£ 150 \mathrm{~m}$ in subscriptions by offering investors a net return of $5 \%$. The new properties would come from Places for People's own development pipeline and from "opportunistic acquisitions from house builders and developers" (cited in IPE, 2017). Thus, Places for People's portfolio of activities now includes being the promoter and fund manager of a private rental vehicle that seeks to attract private equity investors. This new investment vehicle will accelerate the growth of private rental housing relative to social housing in Places For People's property portfolio. Meanwhile, London and Quadrant announced plans to "develop 5,000 private rental homes over the next five years - creating the UK's largest selection of purpose built and newly refurbished rental properties" (L\&Q, 2016, p.26). The following year it purchased a for-profit land trading company for $f, 500 \mathrm{~m}$ to build up its own land bank (Evans, 2017). This acquisition will also enable London \& Quadrant to make profits from rising land values on sites with planning permission.

New rules and practices can result in the emergence of correspondingly new norms that reinforce the new institutional trajectory. But this transition is not automatic or uncontested: retaining the old ethos while accommodating the emerging one can be fraught with contradiction. Thus, Manzi and Morrison's study of the 'G15 group' of large HAs found a disjunction between "a rhetoric of social purpose and the reality of commercial business 
strategy" (Manzi \& Morrison, 2017). As the chief executive of London \& Quadrant acknowledged in an interview with the trade magazine Inside Housing, the growth in their forprofit activity meant they "constantly have to remind ourselves who we are" (quoted in Apps, 2014b). But while there is often resistance at first, over time the new rules and practices gradually become taken-for-granted in everyday discourse and practices. For example, the Housing White Paper, described London \& Quadrant as "a housing association and a leading residential developer" (DCLG, 2017). The IPE news website described Places for People as a "former housing association." Meanwhile, Places for People's website described itself as a "property, development, management, regeneration and leisure company". Tellingly, it now refers to its annual financial surpluses as 'profits'. These examples illustrate just how far these two HAs have travelled from their traditional role as social landlords providing rental homes for low-income and disadvantaged households. They still perform that role, but their profit-focused activities are becoming increasingly important, prompting one of them to question their mission ("who we are", as the Chief Executive of L\&Q put it).

\section{Conclusions}

In this paper, we have examined an apparent puzzle: that large, non-profit 'property developer housing associations' in England are making substantial investments in for-profit rental housing. One has even invested in private rental portfolios overseas. Moreover, while some are letting their private rental homes to their 'traditional' social housing clientele, HAs with the largest private rental portfolios are letting them to more up-market groups of tenants. And yet, waiting lists for social housing have risen and increasing numbers of low-income families are renting on insecure tenancies from private landlords. This shift into for-profit rental housing by property developer HAs - and to more upmarket tenants - would have seemed scarcely conceivable in the 1980s and probably been unacceptable to their committee members.

We have employed an historical institutional approach to examine this puzzle. In doing so, we have drawn upon recent scholarship within this tradition that examines processes of gradual endogenous change that is transformative. This conceptual framework helps us to better understand the dynamics of change over time, and the likely longer-term consequences, of the emerging trend of HA investment in private rental housing. Thus, we have argued that the shift by large developer HA into for-profit landlordism represents a form of 'layering' in which a new set of institutional rules is introduced alongside the existing rules. The rules, everyday practices and norms embodied in private rental housing are typically different from those governing social rental housing. Moreover, the scale of HA investment in private renting is likely to increase over time, and at a faster rate, than their new social housing development. This process of differential growth via layering has the potential, over time, to eventually transform the institutional nature, modus operandi and decision-making calculus of HAs as landlords. As social housing becomes a smaller part of their work, the practices and norms embodied in their increasing for-profit activity could well become hegemonic within property developer HAs.

It is, of course, possible that this growing trend of investment in private rental housing by large property developer HAs could fizzle out, or even reverse, due to changes in domestic housing 
policy or the international political economy. After all, Dutch HAs have recently retreated from an earlier diversification strategy and refocused on their core role of providing social rental housing for lower income households (Nieboer \& Gruis, 2016). And like their Dutch counterparts, HAs in England are not independent of government. For as long as they own social housing that was originally funded by public grants, they will remain subject to the regulatory oversight by government. The HA regulator has a duty to ensure that publicly funded assets are not put at risk by non-social housing activities; and, therefore, could decide to rein back investment in private rental housing if it was felt to be endangering the financial viability of registered HAs in England. However, there seems little prospect that it will bring this emerging trend to a halt, especially in the context of continuing fiscal austerity and shortage of rental housing.

Meanwhile, HAs with small development programmes, operating on modest financial surpluses, and without sufficient assets and risk-management skills to operate in the international capital markets, are unlikely to invest in private rental housing on a substantial scale. Even if the funding outlook for new social rented housing improves, they will be unable to grow at anything like the speed at which the large developer HAs are expanding. Hence, the layering processes we have discussed could eventually lead to a 'premier league' of property developer HAs operating on an increasingly large scale, for whom social housing represents an important, but shrinking, share of their portfolio; and a more slowly growing pool of social developer HAs that remain largely focused on their traditional mission of housing low-income and disadvantaged households.

The paper identified a range of drivers behind this move by property developer HAs into private rental housing, which seem likely to continue for the foreseeable future. These drivers reflect not only changes in housing policy (such as cuts in government grants), but also developments in the international political economy (including the global savings glut, secular decline in interest rates, and the 'search for yield'). These more 'structural' forces have been complemented by 'agency' in the form of ambitious HA chief executives and their management boards keen to increase their size as developers and as landlords, and to expand into more upmarket rental niches. In doing so, these institutional change agents have pushed the boundaries of the institutional rules, working practices and norms that have characterised HA social housing in England. Other large developer HAs may well follow their example. Thus, their growing investment in private rental housing - combined with their build-for-sale, starter homes and shared ownership programmes could eventually raise the question of whether these 'property developer' HAs are any longer primarily social housing landlords. 
Table 1. Private rental dwellings owned by 'top 50' HAs in England

\begin{tabular}{llrrrr} 
& & \multicolumn{2}{c}{$\mathbf{2 0 1 2 / 1 3}$} & \multicolumn{2}{c}{$\mathbf{2 0 1 4 / 1 5}$} \\
\cline { 2 - 6 } $\begin{array}{l}\text { Note: } \\
\text { private }\end{array}$ & Size of private rental portfolio & PR & PR as \% & PR & $\begin{array}{r}\text { PR as \% } \\
\text { Source: }\end{array}$ \\
& & & of all HA & & of all HA \\
& 500 or more in both years & 22,989 & 6.2 & 28,156 & 7.1 \\
& 500 or more in 2014/15 only & 788 & 0.7 & 1,278 & 1.2 \\
& Less than 500 in both years & 3,491 & 0.3 & 4,315 & 0.4 \\
\cline { 2 - 6 } & All HAs with PR portfolios & 27,234 & 1.8 & 33,749 & 2.1 \\
\hline
\end{tabular}

Financial Statements of 'top 50' developing HAs for 2012/13 and 2014/15

Table 2. Recent investment in new private rental dwellings in England

\begin{tabular}{lrr}
\hline Investor type & No. & \% of total \\
\hline Housing association & 6,373 & 23 \\
Housing association/private sector partnership & 865 & 3 \\
Private sector & 18,093 & 66 \\
Local Authority & 2,352 & 8 \\
\hline Total & 27,683 & 100 \\
\hline
\end{tabular}

Sources: Estates Gazette, Financial Times \& Inside Housing: January 2010 to April 2016

Table 3. HA turnover from private rental housing and all 'non-social' housing activity

\begin{tabular}{|r|r|r|r|}
\hline Year & PR turnover & $\begin{array}{r}\text { All 'non-social' } \\
\text { turnover }\end{array}$ & $\begin{array}{r}\text { PR as \% of all 'non- } \\
\text { social' turnover }\end{array}$ \\
\hline & $\mathbf{E m}$ & $\mathbf{E m}$ & $\%$ \\
\hline 2012 & 92 & 784 & 11.7 \\
\hline 2013 & 90 & 870 & 10.3 \\
\hline 2014 & 120 & 983 & 12.2 \\
\hline 2015 & 130 & 879 & 14.8 \\
\hline
\end{tabular}

Note: PR turnover for 2013 to 2015 is interpolated from Figure 7 of 2014 Analysis and Figure 15 of 2015 Global Accounts Source: Homes and Communities Agency, Global Accounts of Housing Providers, 2012, 2013, 2014 \& 2015 


\section{Acknowledgements}

We would like to thank Professor Hal Pawson for helpful comments on an earlier version of this paper. Part of the paper was written while Kemp was a visiting professorial fellow in the City Futures Research Centre at the University of New South Wales. He is very grateful to Professor Bill Randolph and his colleagues for hosting his visit.

\section{Disclosure}

Tony Crook is Deputy Chair of the Orbit Group Ltd, a HA which has invested in private rented housing. No use has been made in this paper of any of the Group's 'commercial in confidence' documents. The paper is entirely based on publicly available data and publications.

\section{Notes}

1. In this paper, we use 'non-profit' as a shorthand term for not-for-profit. By 'social' housing we mean homes let at below-market rents to households assessed as being in housing need.

2. This ambiguity was highlighted by the recent Office for National Statistics' decision to reclassify HAs from 'private' to 'public' organisations for national accounts purposes. The Conservative Government subsequently reclassified back as 'private'.

3. Hall \& Taylor (1996) identified three 'new institutionalisms': rational choice, sociological, and historical. Schmidt (2008) argued there was a fourth: discursive.

4. Mullins et al (2012), Sacranie (2012), Morrison (2016) and Manzi \& Morrison (2017) deploy the concept of 'institutional logics' to examine the conflicting social and commercial organizational priorities of HAs.

5. The name and duties of the quasi-government organisation that regulates HAs in England has changed over time. For ease of exposition we refer to it as the 'HA regulator'.

6. HAs that are charities also have to comply with charity law and be registered with the Charities Commission.

7. These HA subsidies take two main forms. The first is the capital grant provided by central government to HAs. The second is the 'Section 106 scheme' in which new homes are, in effect, subsidized out of the 'planning gain' from land sales to house-builders for residential developments (see Crook et al, 2016b).

\section{References}

Allen, K. (2015) Housing associations seek to profit from Britain's property woes, Financial Times. 29th July

Apps, P. (2014a) Circle eyes up Dutch MR portfolio, Inside Housing 23rd May p5.

Apps, P. (2014b) Sharp rise in turnover from commercial activity, Inside Housing $19^{\text {th }}$ November.

Back, G. \& Hamnett, C. (1985) State housing policy formation and the changing role of housing associations in Britain, Policy and Politics, 13 (4), pp. 393-412.

Billis, D. (2010) Towards a theory of hybrid organisations', in Billis, D. (ed.) Hybrid Organisations and the Third Sector, London: Palgrave pp. 46-69.

Blessing, A. (2012) Magical or monstrous? Hybridity in social housing governance, Housing Studies, 27(2), pp.1892007.

British Property Federation (BPF) (2016) Build to Rent Map of the UK, London: BPF, http://www.bpf.org.uk/whatwe-do/bpf-build-rent-map-uk (last accessed 01.02.2017). 
Brown, C., (2013), Notting Hill's f,500m private sector plan, Inside Housing, 31 May, p 10.

Brown, C (2016a) Agency lowers PfP rating, Inside Housing, 28 ${ }^{\text {th }}$ October, p10.

Brown, C. (2016b) Circle sells German private rental subsidiary, Inside Housing, $4^{\text {th }}$ November, p.10.

Cowans, D. (2012) Why housing associations should take advantage of the private rented sector, Inside Housing, 29th November.

Crawford, C., Emmerson, C., Phillips, D., \& Tetlow, G. (2011) Public spending cuts: pain shared? in Brewer, M., Emmerson, C., \& Miller, H. (eds) The IFS Green Budget, London: Institute of Fiscal Studies.

Crook, A.D.H. \& Moroney, M. (1995) Housing associations, private finance and risk avoidance: the impact on inner cities and urban renewal, Environment \& Planning A, 27(10), pp. 1695-1712.

Crook, A.D.H. et al (2016a) New housing association development and its potential to reduce concentrations of deprivation: an English case study, Urban Studies , 53(16) 3388-3404

Crook A.D.H. et al (2016b) Planning Gain. Providing infrastructure and affordable housing. Oxford: Wiley Blackwell.

Cullingworth, J.B. (1979) Essays on Housing policy. London: George Allen \& Unwin

Czischke, D. (2009) Managing social rental housing in the EU: a comparative study, European Journal of Housing Policy, 9 (2), pp. 121-152.

Czischke, D. (2014) Social Housing Organisations in England and The Netherlands: between the state, market and community, Delft: Technical University of Delft.

Czischke, D., Gruis, V., \& Mullins, D. (2012) Conceptualising social enterprise in housing organisations, Housing Studies 27 (4), pp. 418-437

Department of the Environment (DoE) (1987) Housing, the Government's proposals. Cm 214, London: HMSO.

Department for Communities and Local Government (DCLG) (2017) Fixing Our Broken Housing Market, Cm 9352, London: HMSO.

Duxbury, N (2014) Does size matter? Inside Housing, 26 ${ }^{\text {th }}$ September

Evans, J. (2017) 'London housing association closes in on $f, 500 \mathrm{~m}$ deal for private business', Financial Times, $1^{\text {st }}$ February, p 3 .

O. Fioretos, T.G. Falleti \& A. Sheingate (2016) Historical institutionalism in political science, in O. Fioretos, T.G. Falleti \& A. Sheingate (eds) The Oxford Handbook of Historical Institutionalism, Oxford: Oxford University Press.

Gruis, V. \& Nieboer, N. (2007) Government regulation and market orientation in the management of social housing needs: limitations and opportunities for European and Australian landlords, European Journal of Housing Policy, 7 (1), pp. 45-62.

Gruis, V. (2008) Organisational archetypes for for Dutch housing associations, Environment \& Planning C: Government \& Policy, 26 (6), pp 1077-1092.

Hall, P.A. \& Taylor, R. (1996) Political science and the three new institutionalisms, Political Studies, 44, pp.936-957.

Harloe, M. (1995) The People's Home. social rented housing in Europe and America. Oxford: Blackwell

Hills, J. (1987) When is a grant not a grant? The current system of housing association finance. Discussion Paper 13, Welfare State Programme. London: London School of Economics.

Inside Housing (2013) Places for People has bought 654 flats across England from developer Urban Splash, Inside Housing, 26 July. 
Inside Housing (2014a) Top 50 developing associations ramp up activity for 2015, Inside Housing, 27 th June 2014.

Inside Housing (2016) Going up or going down?, Inside Housing, 1st July, pp. 18-26.

Investment and Pensions Europe (IPE) (2017) Places for People creates property fund management arm IPE Real Estate News, $10^{\text {th }}$ March.

Kemp, P.A. (1990) Shifting the balance between state and market: the reprivatisation of rental housing provision, Environment and Planning A, vol. 22, pp. 793-810.

Kemp, P.A. (2011) Low-income tenants in the private rental market, Housing Studies, 26 (7/8) pp. 1019-1034.

Kemp, P.A. (2015) Private renting after the Global Financial Crisis, Housing Studies. 30(4), pp.601-620.

Krasner, S.D. (1984) Approaches to the state: alternative conceptions and historical dynamics, Comparative Politics, 16(2), pp. 223-246.

London \& Quadrant Housing Association (L\&Q) (2016) Financial Statements 2015-2016, London: L\&Q

Lupton, M., Jones, M., Davies, A. \& Tippireddy, H. (2011) Appreciating assets London: Saviills \& Chartered Institute of Housing.

Mahoney, J \& Thelen, K. (eds) (2010) Explaining Institutional Change: ambiguity, agency, and power, Cambridge: Cambridge University Press.

Malpass, P. (2000) Housing Associations and Public Policy: a historical perspective. Basingstoke: Macmillan.

Manzi, T. \& Morrison, N. (2017) Risk, commercialism and social purpose: repositioning the English housing association sector, Urban Studies, Online First.

March, J. G. \& Olsen, J. P. (2006) Elaborating the 'new institutionalism', in: R. A. W. Rhodes, S. A. Binder \& B. A. Rockman (Eds) The Oxford Handbook of Political Institutions, pp. 3-20 (Oxford: Oxford University Press).

March, J.G \& Olsen, J.P. (2008) The logic of appropriateness, in ed. M. Moran, Rein, M. \& Goodin, R.E. (eds) The Oxford Handbook of Public Policy, Oxford: Oxford University Press.

Merrett, S. (1979) State housing in Britain. London: Routledge \& Kegan Paul.

Morrison, N. (2016) Institutional logics and organisational hybridity: English housing associations' diversification into the private rented sector, Housing Studies, 31 (8) pp. 897-915.

Mullins, D. (2006) Competing institutional logics? Local accountability and scale and efficiency in an expanding non-profit housing sector, Public Policy \& Administration, 21 (3), pp 6-24.

Mullins, D. \& Walker, B. (2009) The impact of direct funding for private developers on non-profit housing networks in England: exploring a research agenda, European Journal of Housing Policy, 9 (2), pp 201-222.

Mullins, D. \& Pawson, H. (2010) Housing associations: agents of policy or profits in disguise? in Billis, D. (ed.) Hybrid Organisations and the Third Sector London: Palgrave pp 197-218

Mullins, D., Czischke, D., \& van Bortel, G. (2012) Exploring the meaning of hybridity and social enterprise in housing organisations, Housing Studies, 27 (4), pp 405-417.

Nieboer, N. \& Gruis, V. (2014) Shifting back-changing organisational strategies in Dutch social housing, Journal of Housing \& the Built Environment, 29 (1), pp 1-13

Nieboer, N. \& Gruis, V. (2016) The continuing retreat of non- profit housing providers in the Netherlands, Journal of Housing \& the Built Environment, 31, pp 277-295.

North, D.C. (1990) Institutions, Institutional Change and Economic Performance, Cambridge: Cambridge University Press 
Pawson, H. \& Milligan, V. (2013) New dawn or chimera? Can institutional financing transform rental housing?, International Journal of Housing Policy, 13 (4), pp. 335-357.

Pawson, H. \& Mullins, D. (2010) After Council Housing: Britain's new social landlords, Basingstoke, Palgrave Macmillan.

Pawson, H. \& Sosenko, F. (2012) The supply-side consequences of social housing in England, Housing Studies, 27 (6) pp783-804.

Pierson, P. (2004) Politics in Time, Princeton University Press: Princeton, N.J.

Places for People Housing Association (PfP) (2016) Creating aspirational homes and inspirational places: annual report and financial statements, 2016, London:: PfP

Randolph, B. (1993) The re-privatization of housing associations, in P. Malpass \& R. Means (eds) Implementing Housing Policy, Open University Press: Buckingham.

Rhodes M.L. \& Mullins, D. (2009 Market concepts, coordination mechanisms and new actors in social housing, European Journal of Housing Policy, 9 (2), pp.107-120.

Rhodes, M.L. \& Donnelly-Cox, G. (2014) Hybridity and social entrepreneurship in social housing in Ireland, Voluntas, 25, pp 1630-1647.

Sacranie, H. (2012) Hybridity enacted in a large English housing association, Housing Studies, 27(4), pp. 533-552.

Sanders, E. (2006) Historical institutionalism, in R.A.W. Rhodes, S.A. Blinder \& B.A. Rockman (eds) Political Institutions, Oxford: Oxford University Press.

Savills UK Residential Research (2013) Montague, one year on. London: Savills.

Steinmo, S., Thelen, K. \& Longstreth, F. (eds) (1992) Structuring Politics: historical institutionalism in comparative perspective, Cambridge: Cambridge University Press.

Schwartz, H. (2009) Subprime Nation: American power, global capital and the housing bubble, Ithaca: Cornell University Press.

Stothard, C. (2016) L\&Q credit rating cut as it revises down forecast surplus, Inside Housing, 3rd November.

Streeck, W. \& Thelen, K. (eds) (2005) Beyond Continuity: Institutional Change in Advanced Political Economies, Oxford: Oxford University Press.

Tang, C.P.Y., Oxley. M. \& Mekic, D. (2016), Meeting commercial and social goals: institutional investment in the housing associations sector, Urban Studies, on line first

Tarn J.N. (1973) Five Per Cent Philanthropy, Cambridge: Cambridge University Press.

Taylor-Gooby, P. (2012) Root and branch restructuring to achieve major cuts: the social policy programme of the 2010 UK Coalition Government, Social Policy \& Administration, 46 (1), pp. 61-82.

Thelen, K. (2004) How Institutions Evolve: the political economy of skills in Germany, Britain, the United States and Japan, Cambridge: Cambridge University Press.

Titmuss, R.M. (1970) The gift relationship: from human blood to social policy. Harmondsworth: Penguin Books

Walker, R.M. (1998) 'New public management and housing associations: from comfort to competition'. Policy \& Politics, 22, pp 71-87.

Walker, R.M. (2000) 'The changing management of social housing: the impact of externalisation and managerialism' Housing Studies 15 (2), pp 281-299.

Wilcox, S. \& Pawson, H. (2013) UK Housing Review 2013, Chartered Institute of Housing: Coventry. 